\title{
Ángulo Recto
}

ISSN: 1989-4015

\section{Crímenes en Río de Janeiro}

Javier Rivero Grandoso ${ }^{1}$

Título: Río Noir

Editorial: Maresia Libros

Coordinador: Tony Belloto

Traductor: Juan Pablo Villalobos

Año: 2016

Número de páginas: 301

El género criminal es seguramente una de las formas narrativas que más prima al espacio urbano. Desde sus orígenes, la novela policíaca, detectivesca, negra, criminal, o como la queramos llamar, ha situado mayoritariamente la ciudad en el centro de la trama. El París de Auguste Dupin, el Londres de Sherlock Holmes, la Barcelona de Pepe Carvalho, la Marsella de Fabio Montale, la Atenas de Kostas Jaritos o La Habana de Mario Conde son ejemplos de la intrínseca relación que se establece entre sagHa policíaca, personaje protagonista y ciudad.

Precisamente por esta conexión entre el espacio urbano y el género criminal la editorial norteamericana Akashic Books lleva años publicando antologías de relatos en su colección "Noir Series" protagonizados por una ciudad concreta. En esta colección, como es obvio desde el punto de vista comercial, hay un gran número de títulos dedicados a ciudades de Estados Unidos, pero también hay espacio para urbes de otros países. Hasta el momento, solo se han publicado tres títulos protagonizados por ciudades del ámbito hispano, Barcelona, La Habana y México D.F., cuatro si se tiene en cuenta San Juan, la capital de Puerto Rico.

Río Noir, el volumen editado por Maresia Libros que vamos a reseñar, es una traducción de la obra homónima publicada por Akashic Books en 2015 y, un año antes, por la editorial brasileña Casa da Palavra. Se trata asimismo de la segunda publicación en España, hasta donde sabemos, de un título de la colección "Noir Series" a la que hacíamos referencia, ya que Barcelona negra fue publicada en 2013 por Edhasa, versión original de la traducción al inglés que publicó Akashic Books dos años antes.

La traducción de Río Noir se publicó en España en junio de 2016, dos meses antes de la inauguración de los Juegos Olímpicos en la ciudad brasileña. No es un hecho casual, sino una inteligente estrategia de marketing, ya que permite a los lectores acercarse a la urbe que será protagonista en los periódicos y en los telediarios durante prácticamente un mes a través de un género social, entretenido y comercial.

La cubierta de esta edición es un collage con los principales símbolos de la ciudad carioca: el Cristo Redentor, varios fajos de billetes, un policía militar, una mujer ataviada con los característicos elementos del carnaval y una panorámica de un barrio. Estas imágenes reflejan las principales nociones que un lector español o europeo tiene de Río de Janeiro a partir de las noticias que llegan de los medios de comunicación: el omnipresente Cristo del Corcovado, su internacional carnaval, el narcotráfico, las favelas, la inseguridad, la corrupción, las fuertes diferencias sociales...

Otro detalle de la cubierta que no debemos pasar por alto es la inclusión del nombre del traductor, Juan Pablo Villalobos, un hecho que dignifica su labor y que permite al lector identificar al responsable de la versión en español. 
En cuanto al contenido, el libro consta de catorce relatos de otros tantos escritores, de los que tan solo dos son mujeres. La antología comienza con una cita de Rubem Fonseca, posiblemente el mejor escritor brasileño de novela negra, que señala la otra cara que posee la urbe brasileña: "la ciudad de Río no es el paraíso que se otea desde el Pão de Açúcar" (9). El prólogo de Tony Belloto, el encargado de la antología de los textos, hace hincapié en las dos caras de una ciudad caracterizada por oscilar entre los extremos. Frente a los problemas sociales, derivados de la pobreza y el narcotráfico, hoteles de lujo y urbanizaciones residenciales para la clase alta. Frente a la violencia crónica de determinados barrios, la presencia de los cuerpos policiales, que intenta dar sensación de seguridad en una ciudad que alberga eventos y celebraciones de calado internacional, como sus populares carnavales, el Mundial de fútbol de 2014 o los Juegos Olímpicos de 2016. Y es precisamente ese otro Río, el alejado de las postales turísticas, el que los autores de esta antología intentan descifrar y representar en sus relatos, fantástica materia prima para el género criminal.

Los cuentos están situados todos en distintas partes de la ciudad, ya que cada escritor se centra en un determinado barrio o una zona concreta.

La antología de relatos está dividida en cuatro partes. La primera es "Ciudad dividida" y consta de cuatro cuentos. Luiz Alfredo Garcia-Roza es el autor de "El botín", protagonizado por Ratón, personaje que se dedica a los negocios de los bajos fondos y que, tras las presiones de un policía, debe huir de la ciudad, aunque para ello tiene que recuperar el dinero que ha conseguido a lo largo de su trayectoria delictiva.

Continúa el relato "El retorno", de MV Bill, ambientado en Ciudad de Dios, en el que Bolha, el joven líder de una mafia dedicada al narcotráfico, ve peligrar su trabajo tras las actuaciones de la policía, aunque se topa con una inesperada ayuda.

Después aparece el cuento del escritor Luiz Eduardo Soares, "Fin de semana en São Conrado", en el que el policía Otto Mursa vive en primera persona el caos que generan los narcotraficantes en Rocinha al huir de la policía. Mursa investiga ese caso, en el que hay intereses ocultos.

El último cuento de esta primera parte es el de Guilherme Fiuza, "RJ-171", en el que Zéu, el líder del narcotráfico en la favela, le perdona la vida a Romário a cambio de que este le consiga una cita con la celebridad Laurinha Guimarães. La trama se complica y pone en serios apuros a los personajes.

La segunda parte lleva el título de "Fuentes murmurantes" y comienza con el relato "Taxi argentino", de Arthur Dapieve, en el que un policía contempla el cadáver de una mujer rubia alta que cayó por un precipicio y que le recuerda a un travesti al que atendió tiempo atrás.

A continuación se presenta el cuento "Punto ciego", de Victoria Saramago, en el que Annie, mujer estadounidense que emigra a Río de Janeiro para, según parece, rehabilitarse de sus adicciones, encuentra un dedo mutilado en la basura.

Le sigue el relato de Arnaldo Bloch, "El enigma del gramófono", que contiene elementos oníricos y que está basado en la reflexión del origen de la palabra Jacarepaguá, barrio de Río.

La tercera parte, titulada "Purgatorio de belleza y caos", comienza con el relato "El ahorcado" de Adriana Lisboa, protagonizado por un hombre que vuelve a su antiguo barrio, Largo do Machado, y que recuerda su historia con una joven que decía ser vidente. Para honrarla, acude a una adivina, lo que cambiará por completo su vida.

Continúa Tony Belloto con el cuento "Maduritas bien conservadas", en el que el protagonista se dedica a seducir a mujeres maduras para conseguir sacarles algo de dinero.

Por último, Alexandre Fraga dos Santos finaliza esta parte con "Caníbal de Ipanema", una narración en la que un exgeneral del ejército con tendencias caníbales contrata a una prostituta.

La última parte lleva por título "Río Babilonia", y comienza con el cuento de Marcelo Ferroni, "Tangerina tango", en el que Humberto Mariconda, que trabaja en una editorial, es testigo directo de la desaparición de Greg Nicholas, un escritor de un best-seller orientado a la pérdida de peso.

Flávio Carneiro es el autor de "La espera", un relato en el que una mujer contrata a un detective para encontrar a un hombre que la perseguía y por el que se siente atraída.

A continuación aparece el relato "La historia de Georges Fullar", de Raphael Montes, en el que un joven escritor descubre que el famoso literato Georges Fullar es su vecino y empieza a entablar una relación con él marcada por la fascinación y la progresiva degradación personal.

Por último, cierra la antología Luis Fernando Verissimo con "El leñador", cuento en el que un reportero cubre la noticia del asesinato de una pareja. 
El conjunto de los relatos muestra una visión variada tanto de la ciudad como del género criminal, con multitud de personajes muy diversos. Tan solo aparece un detective protagonista, lo que ilustra que, al menos en el relato corto, en Brasil los personajes principales suelen ser personas marginales y en menor medida policías, que pueden ser honrados o corruptos. La violencia y la inseguridad son temas que aparecen en la mayoría de los cuentos, elementos que forman parte de esa otra cara de Río que el género criminal debe revelar, ya sea a modo de denuncia o simplemente como reflejo de la cotidianidad de una ciudad de extremos.

Hay muchas cuestiones que deberíamos considerar de este volumen, como la escasez de personajes femeninos protagonistas, las características propias de cada barrio, la poca presencia de turistas o la ausencia del carnaval y de los mega-eventos mencionados, como el Mundial de fútbol o los Juegos Olímpicos. No obstante, tendremos que dejar estos análisis para futuros trabajos, ya que no es este espacio para extensas investigaciones.

Lo que sí debemos resaltar es la magnífica relación que surge de la conjunción del género criminal y el espacio urbano, como queda de manifiesto en esta antología. La idea de crear un libro de relatos que tengan en común el género y la ciudad protagonista no solo se ha llevado a cabo en Estados Unidos, sino que cada vez más editoriales están apostando por esta fórmula en otros países, como España. Desde aquí, nuestra felicitación a Maresia Libros por esta interesante y necesaria iniciativa y nuestro deseo de que continúen traduciendo antologías como esta que pueden funcionar muy bien en el mercado editorial español. 